PALEO

Revue d'archéologie préhistorique

$27 \mid 2016$

Varia

\title{
New dating of the "mask" of La Roche-Cotard (Langeais, Indre-et-Loire, France)
}

Jean-Claude Marquet, Michel Lorblanchet, Christine Oberlin, Edit ThamoBozso and Thierry Aubry

\section{(2) OpenEdition}

Journals

Electronic version

URL: http://journals.openedition.org/paleo/3278

DOI: $10.4000 /$ paleo.3278

ISSN: 2101-0420

Publisher

SAMRA

Printed version

Date of publication: 30 December 2016

Number of pages: 253-263

ISSN: $1145-3370$

\section{Electronic reference}

Jean-Claude Marquet, Michel Lorblanchet, Christine Oberlin, Edit Thamo-Bozso and Thierry Aubry, « New dating of the "mask" of La Roche-Cotard (Langeais, Indre-et-Loire, France) », PALEO [Online], 27 | 2016, Online since 01 June 2018, connection on 07 July 2020. URL : http://journals.openedition.org/ paleo/3278; DOI : https://doi.org/10.4000/paleo.3278

This text was automatically generated on 7 July 2020.

\section{cc) (ㅇ) $\ominus$}

PALEO est mis à disposition selon les termes de la licence Creative Commons Attribution - Pas d'Utilisation Commerciale - Pas de Modification 4.0 International. 


\title{
New dating of the "mask" of La Roche-Cotard (Langeais, Indre-et- Loire, France)
}

\author{
Jean-Claude Marquet, Michel Lorblanchet, Christine Oberlin, Edit Thamo-
} Bozso and Thierry Aubry

We are thanking Francine Fellrath-Bacart for the translation in French of Edit Thamo-Bozso's contribution and also the anonymous reviewers of the journal who have allowed précising the text.

\section{Introduction}

1 The site of La Roche-Cotard, discovered in 1912 after the extraction, in 1846, of materials for the works of the Tours-Angers railway, was excavated at the time of its discovery (d'Achon 1913) and in the second half of the 1970s (Marquet 1979; Marquet et al. 1997; Lorblanchet 1999). Work has resumed there since 2008 (Marquet and Lorblanchet 2000, 2003). The excavation of the 1970s led to the discovery, in front of the entrance to d'Achon cave, of a thick sedimentary deposit, of very restricted dimensions ( $4 \mathrm{~m} \times 2 \mathrm{~m}$ ) that included notably a beach fragment of the Loire River (fig.1). The sediment of layer $7 \mathrm{c}$, the lower part of layer 7 , is a coarse sand containing large fragments of chert and limestone that fill the irregularities of the surface of the substrate. It is overlaid by the same coarse sand ( $7 b)$ mixed with gravels most often laid flat and it ends with a very thin layer (7a), rich in large mica flakes. Layer 6 has a mineralogical composition that is slightly different from layer 7 but it is also a coarse sand topped, like layer 7, by a homogeneous fine sand. Layers 6 and 7 are alluvial in origin, set up during two successive floods of the Loire (Macaire in Marquet et al. 1997, p.76). Layer 7 contained an archaeological level with a lithic industry typical of the Mousterian and rare but well preserved remains of fauna. Refittings between lithic remains of this level indicate that they were not affected by large-scale postdepositional movements (Marquet et al. 1997, 87). This level also included a composite 
object, long called an enigmatic object (Marquet 1979) and named "mask" of La RocheCotard by Michel Lorblanchet.

2 The intentional nature of the making of this object, $93 \mathrm{~mm}$ high, $105 \mathrm{~mm}$ wide, $40 \mathrm{~mm}$ thick and weighing $299 \mathrm{~g}$ (fig. 2), was discussed earlier (Marquet and Lorblanchet ibid). It is based on four criteria: the similar length of the bone fragment on either side of the rocky bridge of the supporting block; the blocking the bone fragment inside the natural hole of the supporting block using small stone plaques neatly visible on the object and on its tomography; the removal of flakes on each of the two faces of the block to create a better symmetry of the object; the straightening of the two ridges in the "lower" part of the object by crushing (the vocabulary used here results from the a priori chosen positioning of the object, such that the face of fig. 2 would be the anterior face).

3 It seems difficult to deny the symbolic characteristic of this production that was discovered within the Mousterian layer. The hypothesis of F. d'Errico (Nicoud 2004) that the object could have been used as a weight for stretching a hanging does not hold because of the very small mass of the object $(299 \mathrm{~g})$ that does seem as complete today as when it was abandoned in the sandy layer. The hypothesis of P. Pettitt (2003) that this object could be the result of a child's play does not seem to be suitable either because if the first two characterization criteria could correspond to this possibility (balance and wedging), on the other hand it does not seem to us that the last two can enter this context (search for symmetry and regularity).

4 Fig. 1: Langeais. La Roche-Cotard II. Stratigraphy and position of the latest four dates obtained. The strings of the sagittal section are one meter apart.

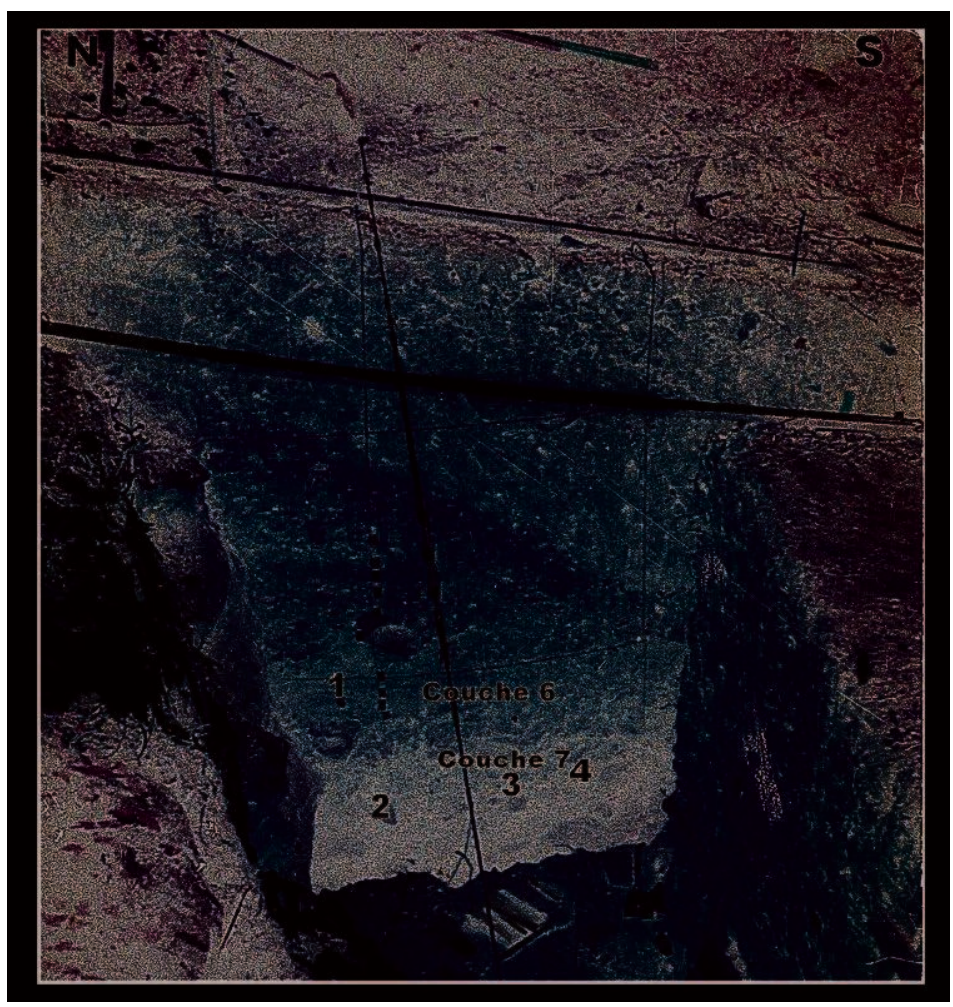


Fig. 2: Langeais. La Roche-Cotard II. The "mask". Height: 93 mm, width: 105 mm, thickness: 40mm, weight: $299 \mathrm{gm}$.

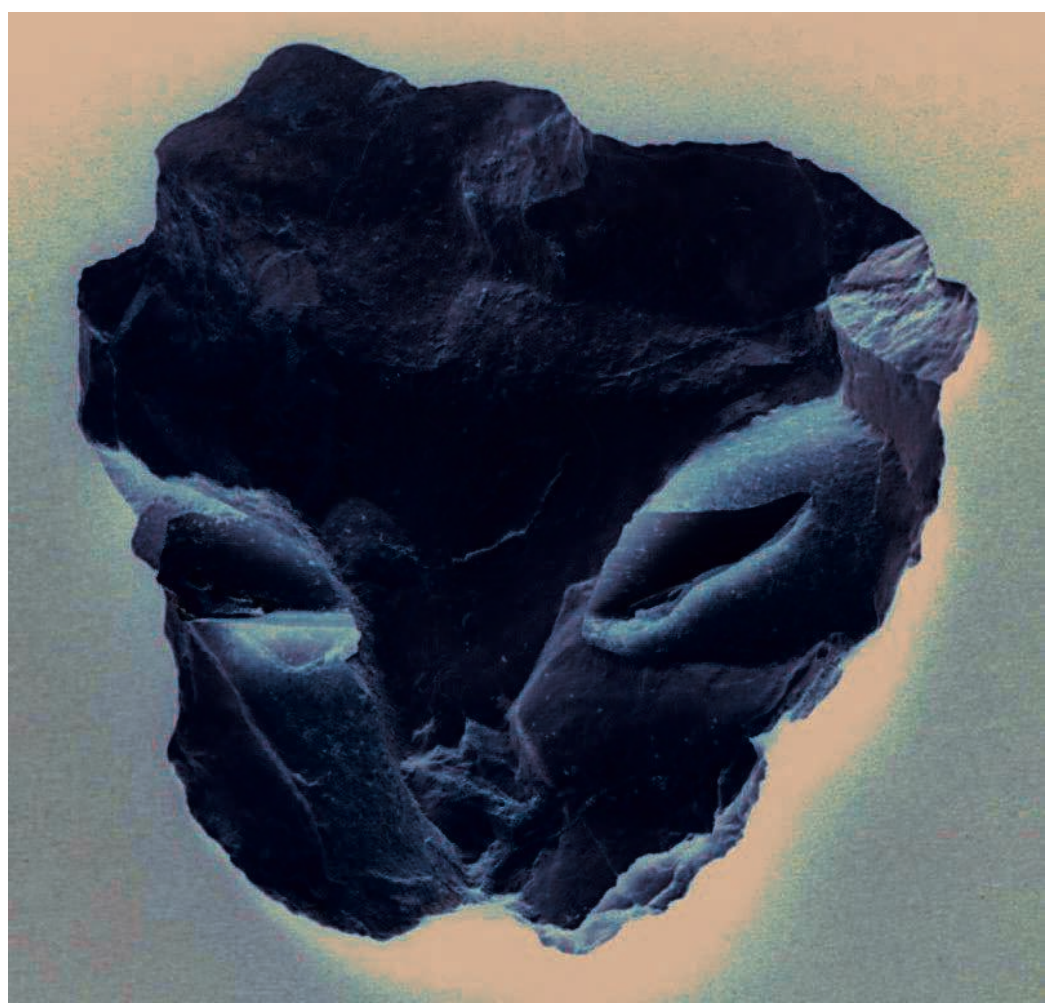

\section{1 - Dating of bone remains by radiocarbon}

On January $10^{\text {th }} 1980$, G. Delibrias of the Gif-sur-Yvette Center for Low Radioactivity (in litteris) indicated an age greater than or equal to $32.1 \mathrm{ka}$ (GIF-4383 of 9-01-1980) for ${ }^{14} \mathrm{C}$ dating carried out on the large herbivore rib found near the hearth basin of layer 7 in La Roche-Cotard II, the layer that gave the "mask". In her accompanying letter, she says that "very old datings, on most materials, are unreliable. For these reasons I have been reluctant to communicate to you the results obtained... I think we must consider the measured ages only as apparent ages giving a lower limit to the real age." It is this date that was published before the resumption of excavations in 2008.

6 From 2009, two new ${ }^{14} \mathrm{C}$ datings were carried out on bones, again from the Mousterian layer that gave the "mask". Done by the radiocarbon center of Villeurbanne, the first dating (Lyon-6963/SacA 19432) indicated an age older than $40 \mathrm{ka}$; the second dating (Lyon-9086-SacA 28353) also gave an age older than $40 \mathrm{ka}$. These two dates were done on bone and in both cases the collagen was treated by ultrafiltration (Higham et al. 2011; Oberlin et al. 2015). More precise ages than those indicated here have been measured by the laboratory, but since we are at the limit of the application of the method, the laboratory did not wish to publish these values (table 1) that although older than the age obtained in 1980, remain far below the dates obtained by the OSL method.

\section{$7 \quad 2$ - Dating by Optically Stimulated Luminescence}

8 In 2014, we reopened La Roche-Cotard II in order to carry out sediment sampling in layers 7c (that of the "mask") and of (alluvial layer located immediately above the 
alluvial layer containing the Mousterian level) (fig. 3). We asked the Geological and Geophysical Institute of Hungary (1145 Budapest Columbus u 17-23 1442 Budapest POBox 106) for two new OSL datings, other samples having been previously measured for the other studied areas of the site (table 1).

Table 1: Langeais. La Roche-Cotard. Radiocarbon and OSL dates.

\begin{tabular}{|c|c|c|c|c|c|c|}
\hline LRC I & & Méthode & Carré & Couche & Numérotation Labo & Date obtenue \\
\hline & Salle des lemmings & $14 \mathrm{C}$ & L9 & c. supérieure & Lyon-6962 SacA 19431 & 39,5 à 35,4 ka calBC ou 41,4 à 37,3 cal BP \\
\hline & Salle des lemmings & OSL & L9 9 & c. supérieure & MFGI/126.1 & $64,1 \pm 5,1 \mathrm{ka}$ \\
\hline & Extérieur cavité & OSL & $Y^{\prime} 08$ & c. moyenne & MFG|*/126.7 & $72,6 \pm 6,0 \mathrm{ka}$ \\
\hline & Extérieur cavité & $14 \mathrm{C}$ & $Y^{\prime} 08$ & c. moyenne & Lyon 11276 (Sac A 37649) & $>40 \mathrm{ka} \mathrm{BP}$ \\
\hline & Galerie moustérienne & $14 \mathrm{C}$ & D 14 & c. moyenne & Gif-4447 & $>38,4 \mathrm{kaBP}$ \\
\hline & Salle des lemmings & $14 \mathrm{C}$ & L9 9 & c. moyenne & Lyon-6961 SacA 19430 & $>40 \mathrm{ka} \mathrm{BP}$ \\
\hline & Galerie moustérienne & $14 \mathrm{C}$ & 114 & c. moust. (c. 3) & Lyon-7864 SacA 23350 & $>40 \mathrm{ka} \mathrm{BP}$ \\
\hline & Entrée & $14 \mathrm{C}$ & C 12 & c. inférieure & Lyon 11273 Sac A 37646 & $>40 \mathrm{ka} \mathrm{BP}$ \\
\hline & Salle du pilier & $14 \mathrm{C}$ & Q 17 & c. 3 & Lyon-7865 SacA 23351 & $>45 \mathrm{ka} \mathrm{BP}$ \\
\hline & Salle de la hyène & $14 \mathrm{C}$ & Y 21 & c. 1 & Lyon-10161 (SacA32828) & $>40 \mathrm{ka} \mathrm{BP}$ \\
\hline \multirow[t]{5}{*}{ LRC II } & Alluvions Loire & OSL & $i 13$ & $6 \mathrm{f}$ & MFGI/136.2 & $65,7 \pm 5,0 \mathrm{ka}$ \\
\hline & Couche moustérienne & OSL & $\mathrm{i} 13$ & $7 \mathrm{c}$ & MFGI/136.1 & $75,6 \pm 5,8 \mathrm{ka}$ \\
\hline & Couche moustérienne & $14 \mathrm{C}$ & f. 12 & c. 7 & Gif-4383 & $>32,1 \mathrm{kaBP}$ \\
\hline & Couche moustérienne & $14 \mathrm{C}$ & $i 13$ & c. 7 & Lyon-6963 SacA19432 & $>40 \mathrm{ka} \mathrm{BP}$ \\
\hline & Couche moustérienne & $14 \mathrm{C}$ & h 12 & c. 7 & Lyon-9086 SacA 28353 & $>40 \mathrm{ka} \mathrm{BP}$ \\
\hline \multirow{4}{*}{ LRC III } & Remplissage abri & $14 \mathrm{C}$ & $?$ & c. XIII & Gif-4384 & $>45 \mathrm{ka} \mathrm{BP}$ \\
\hline & Remplissage abri & $14 \mathrm{C}$ & 17 & c. XIIII & Lyon-10162(SacA 32829) & $>45 \mathrm{ka} \mathrm{BP}$ \\
\hline & Remplissage abri & OSL & 17 & c. XIII & MFGI/126.3 & $56,1 \pm 4,5 \mathrm{ka}$ \\
\hline & Remplissage abri & $14 \mathrm{C}$ & $\mathrm{J} 6$ & c. $X$ & Lyon-10163(SacA 32830) & $>44 \mathrm{ka} \mathrm{BP}$ \\
\hline \multirow[t]{9}{*}{ LRC IV } & Colluvion versant & $14 \mathrm{C}$ & 09 & c. $7 a$ & Lyon 9087 SacA 28354 & 31 à 29,5 ka calBC ou 32,6 à 31,1 calBP \\
\hline & Colluvion versant & OSL & Q 4/Q 5 & c. $7 \mathrm{c}$ & MFGI/126.4 & $48,1 \pm 3,8 \mathrm{ka}$ \\
\hline & Base colluvion versant & $14 \mathrm{C}$ & R4 & c. 9 & Lyon-10160(SacA 32827) & $>44,6 \mathrm{ka} \mathrm{BP}$ \\
\hline & Remplissage grotte-abri & OSL & R3 & c. $12 \mathrm{~cd}$ & MFGI/126.6 & $86,2 \pm 6,5 \mathrm{ka}$ \\
\hline & Remplissage grotte-abri & $14 \mathrm{C}$ & Q 2 & c. $13 \mathrm{~b}$ & Lyon 7863 SacA 23349 & $>45 \mathrm{ka} \mathrm{BP}$ \\
\hline & Remplissage grotte-abri & $14 \mathrm{C}$ & Q3 & c. $13 \mathrm{~d}$ & Lyon 7862 SacA 23348 & $>45 \mathrm{ka} \mathrm{BP}$ \\
\hline & Remplissage grotte-abri & $14 \mathrm{C}$ & Q 3 & c. 15 & Lyon 9088 SacA42835 & $>40 \mathrm{ka} \mathrm{BP}$ \\
\hline & Remplissage grotte-abri & $14 \mathrm{C}$ & Q 1 & c. $16 \mathrm{a}$ & Lyon 9089 (Sac A 28356) & $>40 \mathrm{ka} \mathrm{BP}$ \\
\hline & Remplissage grotte-abri & OSL & Q 4 & c. 22 & MFGI/126.5 & $189,4 \pm 14,9 \mathrm{ka}$ \\
\hline
\end{tabular}
Director : Dr. Tamas Francsik., Operator : Dr. Edit Thamo-Bozso.

Fig. 3 : Langeais. La Roche-Cotard II. Positions of the two samples for OSL dating. A for level 7c and $B$ for level $6 f$.

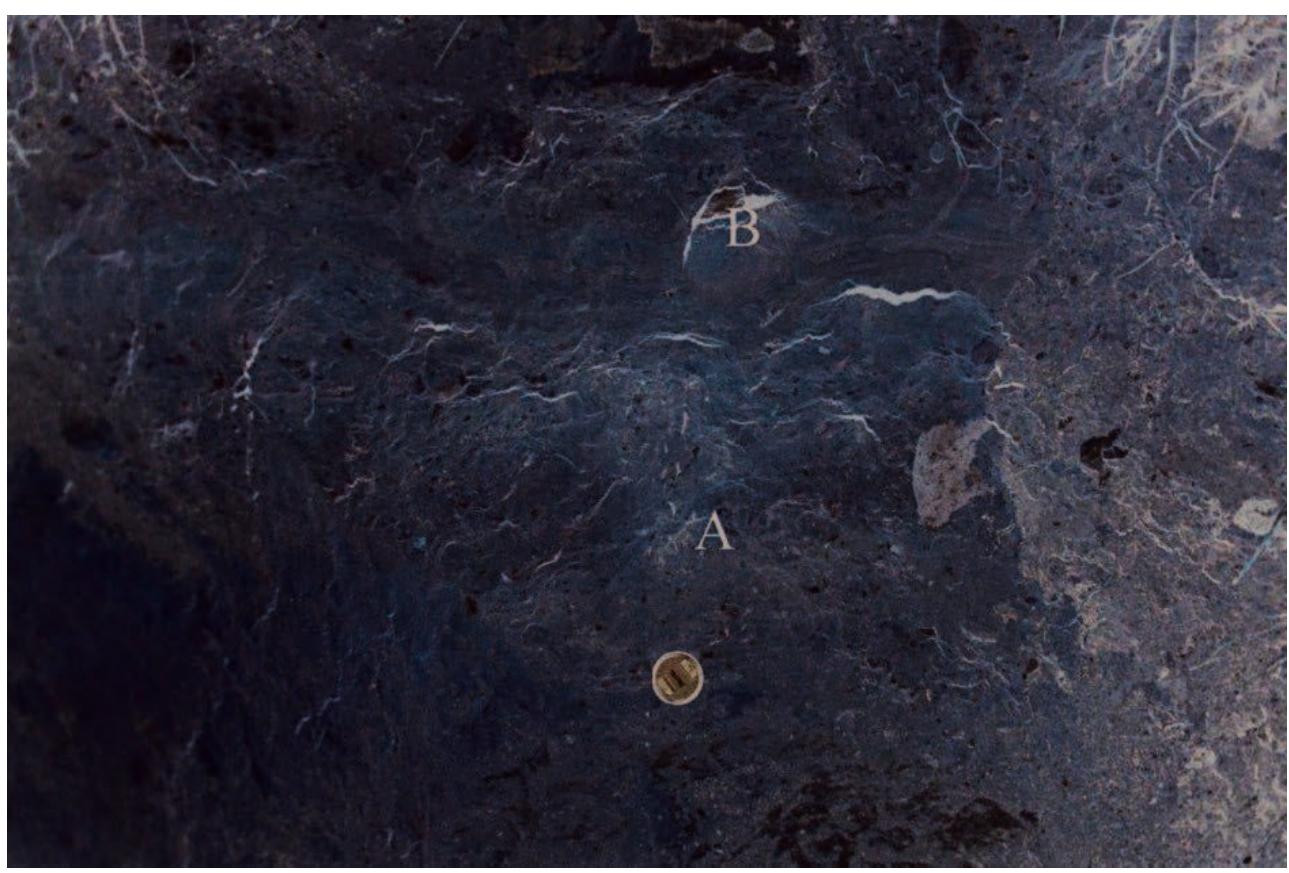

OSL dating is well suited to dating sediments since they are likely to have been bleached during their deposit. The single aliquot technique was applied to La RocheCotard sediment samples. It makes it possible to measure a large number of fractions, 
assumed to be analogous, of the sample to be dated. The OSL dating of the two samples was done on quartz grains with a diameter between 0.10 and $0.16 \mathrm{~mm}$. The protocols for the preparation and measurement of the samples have been appended to our note.

The retained age of the sample of layer $6 \mathrm{f}$ ( $\mathrm{RSC} / \mathrm{LSO} / 9)$, identified by the laboratory under number MFGI / 136.2, is $65.7 \pm 5.0 \mathrm{ka}$ (see appendix). The age of layer $7 \mathrm{c}$ containing the Mousterian level and the "mask" (RSC/LSO/8) is $75.6 \pm 5.8 \mathrm{ka}$. MFGI / 136.1.

\section{3 - Discussion}

11 La Roche-Cotard site is currently the subject of a collective research project whose main objective is to determine its chronology, understand its geological genesis and the nature of the anthropogenic and animal occupations of its four parts. Productions of a symbolic nature, probably unrelated between them, an object called "the mask of La Roche-Cotard" found within a Mousterian layer (LRC II), tracings (digital and other) as well as very rare stains of ochre make it more necessary to try and achieve the chronological objective in particular. The problem is also complex because of a certain isolation of the site that is surrounded, with regard to the stratified deposits containing industries of the Middle Paleolithic, only by the sites of Roches d'Abilly, $50 \mathrm{~km}$ in the south-east (Aubry et al. 2012, 2014a, 2014b), Roc-en-Pail in Chalonnes-sur-Loire, $60 \mathrm{~km}$ to the west (Gruet 1984; Soriano 2012), the site of Angé in Loir-et-Cher, $50 \mathrm{~km}$ to the west (Locht et al. 2015). One can quote only the memory of the Champs-Penais site, again by the town of Abilly, whose stratigraphy and archaeological contents are poorly known (Cordier and Berthouin 1956).

Concerning La Roche Cotard, the age obtained by OSL on the sediment of the base of the LRC IV sequence $(189.4 \pm 14.9 \mathrm{ka})$ indicates its deposit is contemporary to the end of the isotopic stage 7 or else to the beginning of stage 6 (fig. 4); it anchors firmly over time the filling dynamics. Although it was a glacial episode, it does not seem that we have any trace of colluvium, which is quite possible if the river is immediately down the slope, taking away the materials as and when they accumulate. It is also possible that there was accumulation in the absence of the river but release after its return. 
Fig. 4: Langeais. La Roche-Cotard. Position of some OSL dates on the reference curve of oceanic $ð$ ${ }^{18} 0$ variations for the last 200,000 years, corrected according to the earth's orbit (Imbrie et al., 1984).

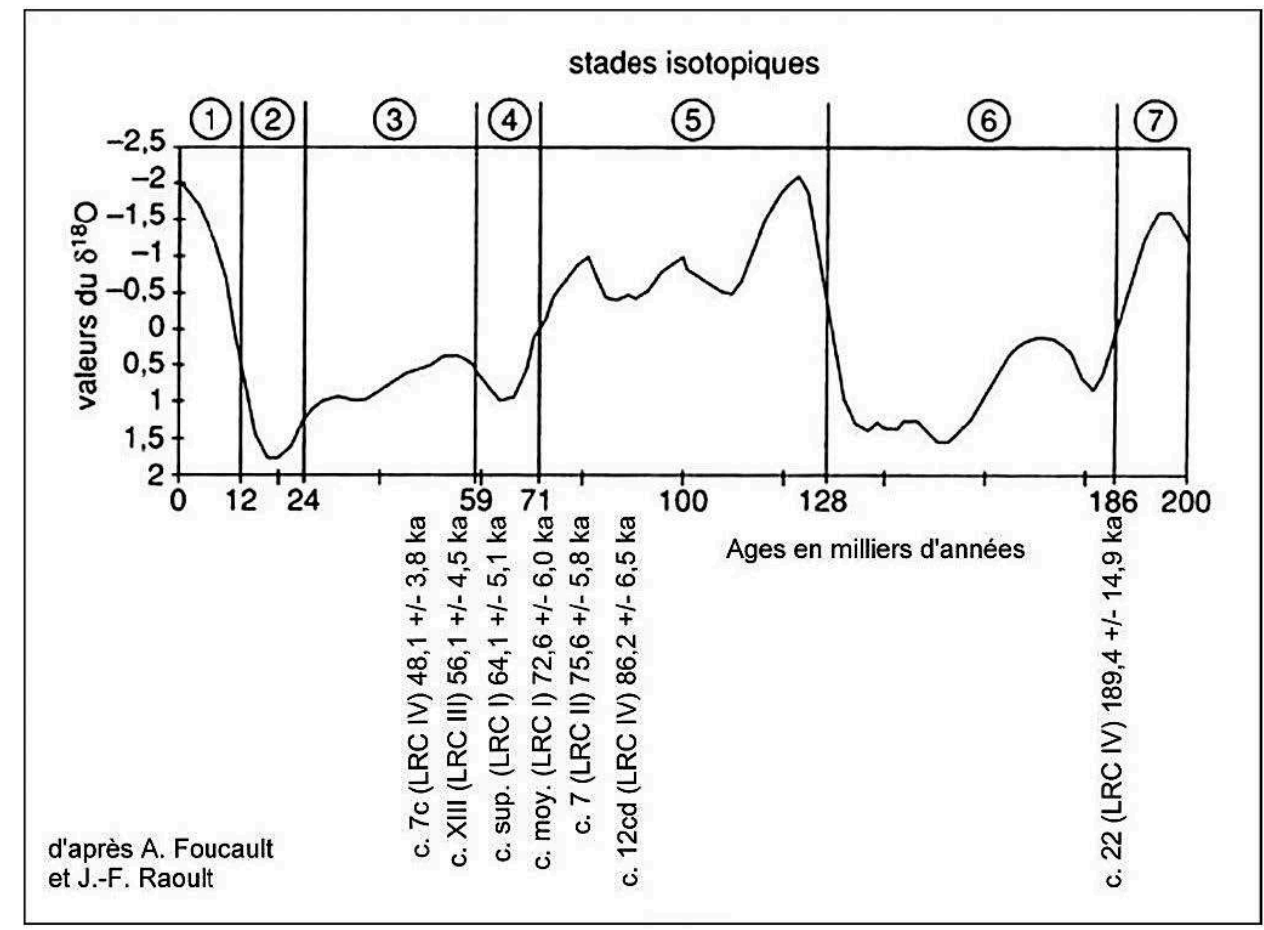
the lower Turonian originating from fluvial terraces or Cretaceous or Cenozoic flints coming from several regional sources of the Loire basin and its tributaries. The flakes, with thinly facetted and narrow butts were obtained on Levallois cores with low convexity. It is possible to reconstitute one of them thanks to a refitting between two flakes (fig.5). A single corresponding core, accidentally broken during its shaping, was discovered. The retouched toolkit is represented by different types of simple or convergent scrapers, prepared on this type of blanks. According to the raw materials employed, several appear to have been produced elsewhere than in the excavated area. 
In association with these retouched tools and in the immediate vicinity of the "mask" a simple convex scraper with double patina was discovered. Unlike the rest of the lithic industry, it was retouched on a flake obtained according to a Levallois scheme with preferential flake (Boëda 1994; Delagnes et al. 2007) and made of flint from a more distant origin, from the Upper Turonian of the Grand-Pressigny region (Indre-et-Loire).

Fig. 5 : Langeais. La Roche-Cotard II. Refitting of two Levallois flakes from the level 7.

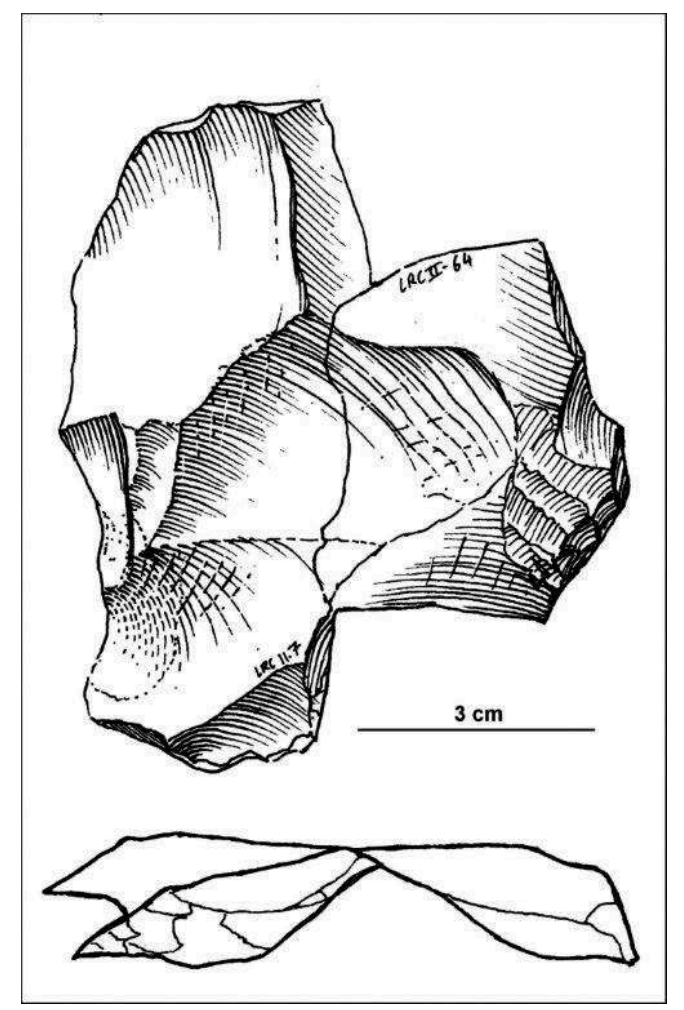

17 This mode of debitage of large flakes according to a preferential Levallois operating scheme that resulted in characteristic cores is known for numerous surface series in the Touraine, Poitou and Brenne regions, sometimes associated with a few bifaces (Primault 2003; Aubry and Rigaud 2004; Aubry et al. 2014b). The chronology of these industries can only be based on the large Levallois flakes produced according to this principle of debitage and discovered in place in layer 5 of the sector LRA Virage 31/35 of the Roches d'Abilly site. This layer has been measured by several methods of luminescence on quartz and feldspar grains (OSL). Two of the methods provide preliminary results that are coherent and would place this occupation between 58 and $76 \mathrm{ka}$ (Aubry et al. 2014b), in line with the statistical age difference for layer 7 of La Roche Cotard II and for layer 6 that is directly subjacent.

The Levallois method with preferential flake is demonstrated in the North of France "in rather old Mousterian assemblages, prior to the last glacial period" (Delagnes et al. 2007: 216). The new data obtained at La Roche-Cotard and Roches d'Abilly confirm this hypothesis and an attribution at the end of the isotopic stage 5. Nevertheless, the chronology and contemporaneity of the numerous series using Levallois debitage with large preferential flakes in the North and Center-west of France remains hypotheses.

The lithic, discovered by d'Achon in 1912 in the first part of the cave (LRC I) is unfortunately lost today. According to what can be observed of the bifaces on the 
photographs available, this industry is in all likelihood to be related to a Mousterian of Acheulean tradition (MTA) and to the isotopic stage 3. Indeed, the latter differ technologically and typologically from the bifacial pieces of the site of Angé (Loir-etCher) that was attributed to stage $5 \mathrm{a}$, found in a pedo-sedimentary context of gray forest soil (Locht et al. 2015). The attribution to a recent industry of the Middle Paleolithic of this occupation of La Roche-Cotard I was further confirmed by the discovery of a fragment of a triangular biface in a chamber further from the entrance during excavations subsequent to 2008 (fig. 6).

From a technological point of view, some fragments from layer $12 \mathrm{c} / \mathrm{d}$ of La RocheCotard IV indicate a production according to the same Levallois operating scheme of recurrent centripetal type as that which prevails in layer 7 of La Roche-Cotard II.

On the other hand, the small assemblage of the base of the filling of La Roche-Cotard III, which allowed a high rate of refittings, reveals a production of flakes according to a discoid debitage scheme from flint pebbles. This production mode, although ubiquitous in the Middle Palaeolithic period (Thiébaut, 2007; Jaubert 2010; Jaubert et al. 2003; Mourre 2003), is demonstrated in the region around $45 \mathrm{ka}$ in the D2 layer of the BordesFitte rock shelter (Aubry et al. 2014a). The OSL dates indicate that this occupation of La Roche-Cotard III must be to the most recent occupation phase of the site during the Middle Paleolithic.

\section{4 - Conclusions}

The research on La Roche-Cotard site is part of a current trend of research that accumulates the evidence of very ancient symbolic activities, largely before the arrival of modern Man, especially among the Neanderthals.

In the early 1990s, speleologists discovered in the vast cavern of Bruniquel (Tarn et Garonne) $300 \mathrm{~m}$ from the entrance, that is to say in the deep dark zone, a strange closed oval structure of $7 \mathrm{~m} \times 4 \mathrm{~m}$ constituted a mass of stalagmites and various concretions. At the southern end there is also another ring of broken concretions, of round shape, about $2 \mathrm{~m}$ in diameter. In the vicinity, speleologists have noticed the presence of clay pellets projected on the gallery ceiling (Rouzaud et al. 1996), but these remains may not be those of a traditional dwelling, although the structure may evoke the Mousterian hut of Molodova (Ukraine), whose skins were kept at the base by a large ring of mammoth bones. No tools, nor real traces of occupation have been identified for the moment in this structure. However, a burned cave bear bone (probable trace of a "lighting" position) had been dated by radiocarbon to $47.6 \mathrm{ka}$ BP, which corresponded to the ultimate limits of the carbon 14 dating method. New dating by Uranium-Thorium have just been carried out on stalagmites sealing or constituting the large structure. The obtained result of 176.5 ka places the construction of the structure in a period corresponding to an old phase of the Middle Paleolithic (Jaubert et al. 2016).

New searches, and perhaps excavations, will undoubtedly clarify these first data, but already Bruniquel's discovery shows the penetration in the dark depths of the caves by Mousterian people controlling lighting and the use of the caves for most probably ritual activities, i.e. not directly related to immediate imperatives of everyday life. 
Fig. 6 : Langeais. La Roche-Cotard I. Pilar room. Triangular biface.

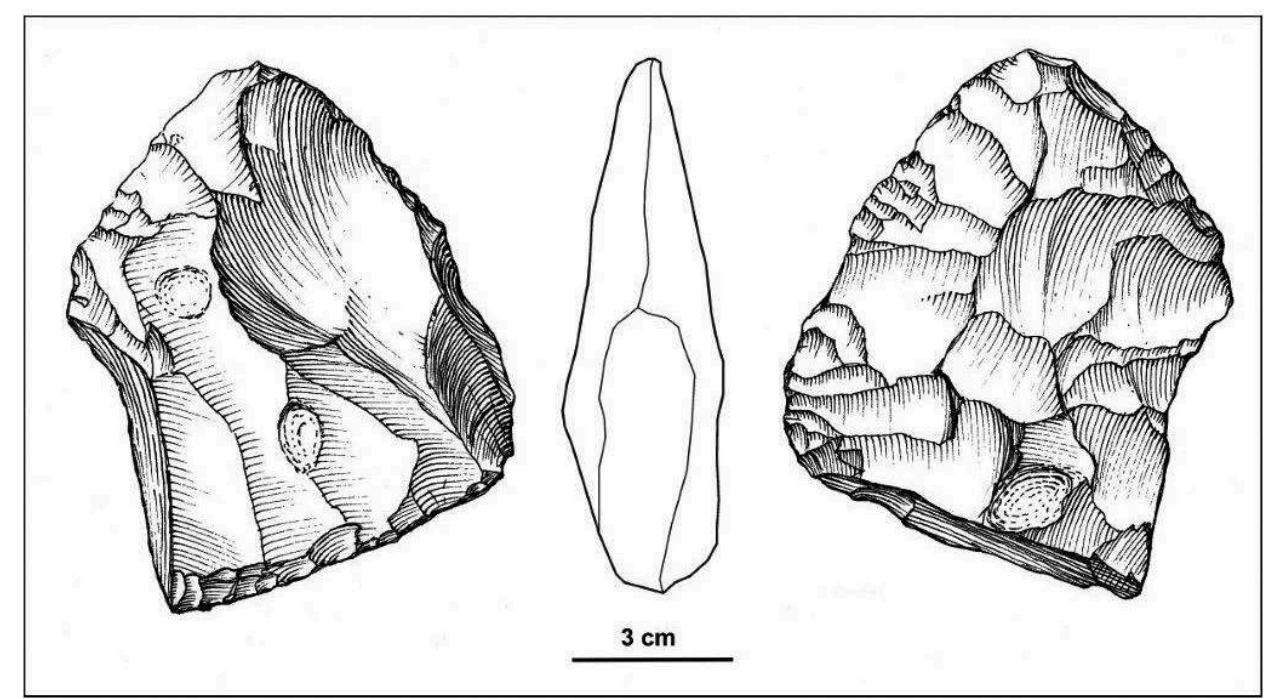
minimum of $37,630 \pm 340 \mathrm{BP}$, by the U-Th dating of the calcite film covering the paintings. This method was developed by a European team of researchers including physicists, geologists and prehistorians (CENIEH laboratory in Burgos). A large red punctuation of the same cave was dated by the same method between $34,250 \pm 170$ and $37,720 \pm 260$. Some dates associated with red patterns of the Altamira cave would even reach 41,000 years. These dates and methods put forward the hypothesis that Neanderthal people authored the first parietal interventions (Pike et al. 2012 and Pike and Pettitt 2012).

In 2016, a new study of the block with cup-marks of the Mousterian burial No. 6 of La Ferrassie (Dordogne) excavated by L. Capitan and D. Peyrony (Peyrony 1934) confirmed and developed the observations of the first excavators. Using photogrammetric tracings (with equidistant contours of $1 \mathrm{~mm}$ ) and experiments, we showed that this block of Coniacian limestone covering the burial of a Neanderthal child actually had 30 cup-marks on its lower face turned towards the skeleton. These artificial cup-marks were probably obtained with different tools (pebbles and points) at perhaps different times, which supports the hypothesis of collective ritual operations in relation to a burial (Lorblanchet and Bahn 2017). Finally, the abstract motif carved on the bedrock of Gorham's Cave in Gibraltar, whose deep tracings have been covered by a Mousterian archaeological level, thus giving these traces an age greater than 39 ka. (RodriguezVidal et al. 2014).

Thus the existence of a symbolic expression 50,000 years ago, and even beyond that, largely preceding the Upper Paleolithic, and a probable origin of European rock art in the Middle Paleolithic, are becoming clearer. It is becoming increasingly evident that in other parts of the world, symbolic activities predate the Middle Paleolithic (Lorblanchet and Bahn ibid)

In this sense, the new 75 ka datings (layer 7c/A in fig. 3) and 65 ka (layer 6f/B in the same figure) complete the existing series (table 1) and confirm, while précising it considerably, the old dating obtained on bone by the radiocarbon method in 1980 that indicated an age greater than 32.1 ka for layer 7 .

PALEO, 27 | 2016 
With the obtaining of a set of OSL dates, the understanding of the nature and rhythms of the occupation of La Roche-Cotard was enriched chronologically. New dates are in progress that will probably help to clarify a little more the chronology of this complex site but, in any case, it should now be considered that the "mask" of La Roche-Cotard comes from a Mousterian layer that has been dated by the OSL method of an age of the order of $75 \mathrm{ka}$.

\section{BIBLIOGRAPHY}

\section{References}

ACHON (d') F. 1913 - Au pays des châteaux. La Roche-Cotard. Sa grotte préhistorique. La Touraine 1ère année, $n^{\circ} 4$.

AUBRY T., RIGAUD A. 2004 - Les industries Levallois sur éclats en Brenne. In: P. Paillet (dir.) Catalogue de l'exposition : "Préhistoire du Val de Creuse en Berry", Argenton, p. 35-36.

AUBRY T., DIMUCCIO L.-A., ALMEIDA M., BUYLAERT J.-P., FONTANA L., HIGHAM T., LIARD M., MURRAY A., NEVES M.-J., PEYROUSE J.-B., WALTER B. 2012 - Stratigraphic and technological evidences from the Middle Palaeolithic-Châtelperronian-Aurignacian record at the Bordes-Fitte Rockshelter (Les Roches d'Abilly site, Central france) Journal of Human Evolution, vol. 62, p. 116-137.

AUBRY T., DIMUCCIO L.A., BUYLAERT J.P., LIARD M., MURRAY A.S., JØRKOV THOMSEN K., WALTER B. 2014a - Middle-to-Upper Palaeolithic site formation processes at the Bordes-Fitte rockshelter (Central France). Journal of Archaeological Science, 52, p. 436-457.

AUBRY T., WALTER B., PEYROUSE J.-B. 2014b - Paléolithique moyen et supérieur de la vallée de la Claise : bilan de vingt ans d'études et nouvelles perspectives. Bulletin des Amis du Musée de Préhistoire du Grand-Pressigny, n65, p. 9-29.

BOËDA E. 1994 - Le concept Levallois : variabilité des méthodes. Monographie du CRA nº, Paris, CNRS Editions, 280p.

CORDIER G., BERTHOUIN F. 1956 - L'abri Reignoux. Abilly (Indre-et-Loire), in : Congrès préhistorique de France, Compte-rendu de la XV session, Poitiers- Angoulême : p. 97-100.

DELAGNES A., JAUBERT J., MEIGNEN L. 2007 - Les techno-complexes du Paléolithique moyen en Europe occidentale dans leur cadre diachronique et géographique. In : Les Néandertaliens : Biologie et culture. Paris, Éditions du CTHS (Documents préhistoriques, 23), p. 213-229.

GRUET M. 1984 - L'apport de deux sites angevins à la chronologie des terrasses fluviatiles : Rocen-pail en Chalonnes-sur-Loire et Port-Launay sur la Sarthe. Bulletin de l'association française pour l'étude du Quaternaire, 1984 (1,2,3), p. 13-18.

HIGHAM T. 2011 - European Middle and Upper Palaeolithic radiocarbon dates are often older than they look: problems with previous dates and some remedies. Antiquity 85 (327), p. 235-249. 
IMBRIE J., HAYS J.D., MARTINSON D.G., MCINTYRE A., MIX A.C., MORLEY J.J, PISIAS N.G., PRELL W.L., \& SHACKLETON N.J. 1984 - The orbital theory of Pleistocene climate: support from a revised chronology of the marine $\mathrm{d} 180$ record. In: A.L. Berger, J. Imbrie, J. Hays, G. Kukla \& B. Saltzman (eds.), Milankovitch and Climate. Part I, Reidel Publ. Comp., Dordrecht, p. 269-305.

JAUBERT J. 2010 - Le Moustérien ou les sociétés néandertaliennes du Paléolithique moyen en France. In : Clottes, J. (ed.), La France préhistorique, un essai d'histoire. Paris, Gallimard, p. 64-92.

JAUBERT J., BORDES J.G., DISCAMPS E., GRAVINA B. 2011 - A New Look at the end of the Middle Palaeolithic Sequence in Southwestern France. In: Derevianko, Shunkov (ed.), Characteristic Features of the Middle to Upper Paleolithic Transition in Eurasia. Novosibirsk, Asian Palaeolithic Association, p. 102-115.

JAUBERT J., VERHEYDEN S., GENTY D., SOULIER M.,HAI CHENG, BLAMART D., BURLET C., CAMUS H., DELABY S., DELDICQUE D.,EDWARDS L. R., FERRIER C. LACRAMPE-CUYAUBERE F., LEVEQUE F., MAKSUD F., MORA P., MUTH X., REGNIER E., ROUZAUD J.-N., SANTOS F. 2016 - Early Neandertal constructions deep in Bruniquel Cave in south-western France. Nature, le 25 mai 2016. DOI: 10.1038 /nature18291.

LOCHT J.-L., COUTARD S., SORESSI M., KIEFER D., KOEHLER H., DEBENHAM N. 2015 - Angé (Loiret-Cher) : un site moustérien à influences multiples. Mémoire 59 de la Société Préhistorique française. «Les plaines du Nord-Ouest : carrefour de l'Europe au Paléolithique moyen? » Ch. 6, p. 101-125.

LORBLANCHET M. 1999 - La Naissance de l'art. Genèse de l'art préhistorique. Errance.

LORBLANCHET M. et BAHN P. 2017- "'The First Artists; in search of the world's oldest art", 260 p. Thames and Hudson à paraître en 2017

MARQUET J.-C. 1979 Le site paléolithique moyen de la Roche-Cotard, commune de Langeais (Indre-et-Loire) Congrès Préhistorique de France 21e Session Montauban-Cahors, 1979, Vol. 2, p. 189-206

MARQUET J.-C., AUBRY T., BYRNE N., DELPECH F., DESSE G., MACAIRE J.-J., PRAT F., RAGE J.-C., URBAN B., VISSET L. 1997 - Le site préhistorique de La Roche-Cotard à Langeais (Indre-et-Loire). Ed. CLD Chambray-les-Tours, 127 p., 82 fig, 24 tabl., 6 pl. hors texte.

MARQUET J.-C., LORBLANCHET M. 2000 - Le masque moustérien de La Roche-Cotard, Langeais (Indre-et-Loire), Paleo, ${ }^{\circ} 12$, p. 325-338.

MARQUET J.-C., LORBLANCHET M. 2003 - A Neandertal face ? The protofigurine from La RocheCotard, Langeais (Indre-et-Loire, France) », Antiquity volume 77, n²98, p. 661-670.

MOURRE V. 2003 - Discoïde ou pas discoïde ? Réflexions sur la pertinence des critères techniques définissant le débitage discoïde. In : Discoid lithic technology: Advances and implications, ed. M. Peresani, British Archaeological Reports International Series 1120, p. 1-18.

NICOUD L. 2004 - "L'art néandertalien : réalité et énigme". Archéologia, 407, Janvier 2004.

OBERLIN C., VALLADAS H. 2015 - Datation par le Radiocarbone de la fraction organique de l'os, In : Balasse M., Brugal J.-P., Dauphin Y., Geigl E.-M., Oberlin C. et Reiche I, (Eds.), Message d'os. Archéométrie du squelette animal et humain. Editions des archives contemporaines, Collection Sciences Archéologiques, Paris, p. 287-306

PETTITT P. 2003 - Is this the infancy of art? Or the art of an infant? A possible Neanderthal face from La Roche-Cotard, France. Before Farming (Western Academic \& Specialist Press) 11 (3).

PEYRONY D. 1934 - "La Ferrassie", Préhistoire t.3, p.1-92. 
PIKE A.W.G., HOFFMANN D.L., GARCIA-DIEZ M., PETTITT P., ALCOLEA J., BALBIN R. de, GONZALESSAINZ G., LAS HERAS C., LAS HERAS J.A., MOTES R. et ZILHAO J. 2012 - U-Series Dating of Palaeolithic Art in 11 caves in Spain, SCIENCE, vol 336, 15, june 2012, p. 1409-1413.

PIKE A.W.G. and PETTITT P. 2012 - Redating Ice Age Art; were Neandertals the first artists in Europe. Current World Archaeology, Issue 55, p. 22-27.

PRIMAULT J. 2003 - Exploitation et diffusion des silex de la région du Grand-Pressigny au Paléolithique, thèse de l'université de Paris 10-Nanterre, 358 p.

RODRIGUEZ-VIDAL J., d'ERRICO F., ,GILES PACHECO F., BLASCO R., ROSELL J., JENNINGS R. P., QUEFFELEC A., FINLAYSON G., DARREN A.,GUTIERREZ LOPEZ J. M., CARRION J. S., NEGRO J. J., FINLAYSON S., CACERES L. M., BERNAL M. A., FERNANDEZ JIMENEZ S., FINLAYSON C. 2014 - A rock engraving made by Neandertals in Gibraltar. Proceedongs of the National Academy os Science of the United States of America (PNAS) vol. 111 nำ37, p. 13301 -13306

ROUZAUD F., SOULIER M., LIGNEREUX Y. 1996- La grotte de Bruniquel (Tarn et Garonne), Spelunca $\mathrm{n}^{\circ} 60$, p. $27-34$

SORIANO S. 2012 - Roc-en-Pail (Chalonnes-sur-Loire, 49). Une séquence de référence pour le Paléolithique moyen du Centre-Ouest. Demande d'opération archéologique. Dossier scientifique. Ministère de la Culture/DRAC Pays-de-la-Loire/Service régional de l'archéologie. 49 pages.

THIÉBAUT C. 2007 - Le Moustérien à denticulés des années 1950 à nos jours : définitions et caractérisation. Bull. Soc. Préhist. Fr. 104 (3), p. 461-481.

\section{APPENDIXES}

\section{Appendix}

\section{Sample preparation}

OSL dating of two samples was carried out on quartz grains between 0.10 and $0.16 \mathrm{~mm}$ in diameter. Sample preparation was done in dark room under subdued red light conditions. Organic material was removed by $20 \% \mathrm{H}_{2} \mathrm{O}_{2}$, carbonates were dissolved by $10 \% \mathrm{HCl}$. Feldspars and the outer $10 \mu \mathrm{m}$ layer from the quartz grains (which absorbed a dose from alpha radiation) were removed by $40 \%$ HF for 60 minutes (Aitken 1998). Then the quartz fractions were cleaned by $10 \% \mathrm{HCl}$, and the grains were mounted on stainless-steel discs in a $5 \mathrm{~mm}$ diameter (medium aliqouts) monolayer using silicone spray.

\section{OSL measurements and results}

OSL measurements were made using a Risø TL/OSL DA-15C/D automatic reader with a calibrated $90 \mathrm{Sr} / 90 \mathrm{Y}$ beta source. Blue light emitting diodes (LEDs, $\lambda=470 \pm 20 \mathrm{~nm}$ ) were used for the optical stimulation of quartz for $40 \mathrm{~s}$ at $125^{\circ} \mathrm{C}$. The resulted OSL signals were collected through an UV filter (Hoya U-340). Single-Aliquot Regenerative-dose (SAR) protocol was used to estimate equivalent doses with illumination for $40 \mathrm{~s}$ at $280^{\circ} \mathrm{C}$ in the last step of each cycle (Wintle and Murray 2006). 
The quartz separates gave bright luminescence and their signals decreased rapidly (fig. 7). Infrared stimulation test indicated that the measured mineral separates were pure quartz. According to the preheat plateau test and thermal transfer test $260^{\circ} \mathrm{C}$ preheat temperature and $200^{\circ} \mathrm{C}$ cutheat were applied, when the thermal transfer is negligible, maximum $0.085 \%$ of the natural dose. Dose recovery ratio of the samples is $0.98 \pm 0.01$ in average, indicating that the SAR protocol correctly measures the given dose. Figure 8 shows the dose response growth curves of the samples. Only a few measured subsamples (aliquots) were saturated (3 for sample 161.1 and only one for 161.2) and not used for dating.

Equivalent doses were measured and based on $\mathrm{D}_{\mathrm{e}}$ values of 33 subsamples (aliquots) of sample 136.1. and 33 subsamples of sample 136.2.and showed more or less symmetric distribution (fig. 9), therefore the luminescence ages were calculated by the average $\mathrm{D}_{\mathrm{e}}$ value of each sample $(156.15 \pm 2.89 \mathrm{~Gy}$ for sample 136.1 . in $7 \mathrm{c}$ layer and $138.18 \pm 2.50 \mathrm{~Gy}$ for sample 136.2. in $6 \mathrm{f}$ layer, Tabl. 2).

Fig. 7 : Langeais. La Roche-Cotard II. OSL Signals 136.1 and 136.2.
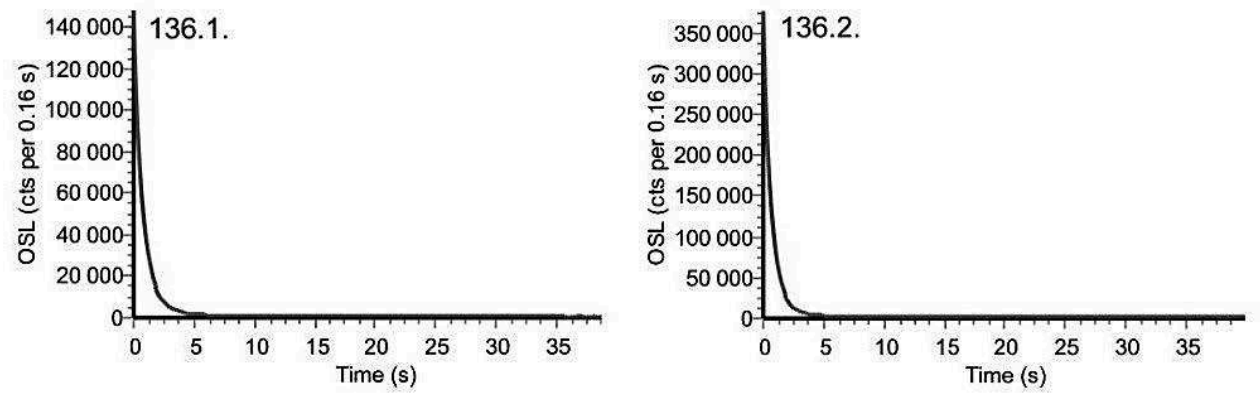

Fig. 8 : Langeais. La Roche-Cotard II. OSL growth curves 136.1 (calculated on 36 aliquots) and 136.2 (calculated on 34 aliquots).

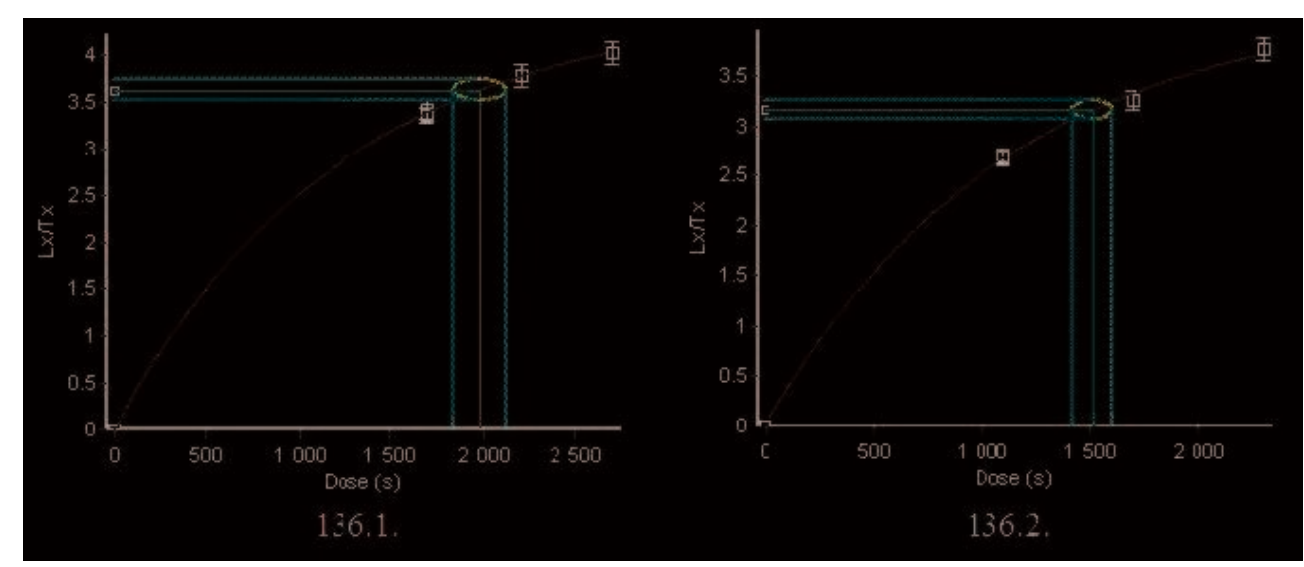


Fig. 9 : Langeais. La Roche-Cotard II. OSL histograms 136.1 and 136;2.
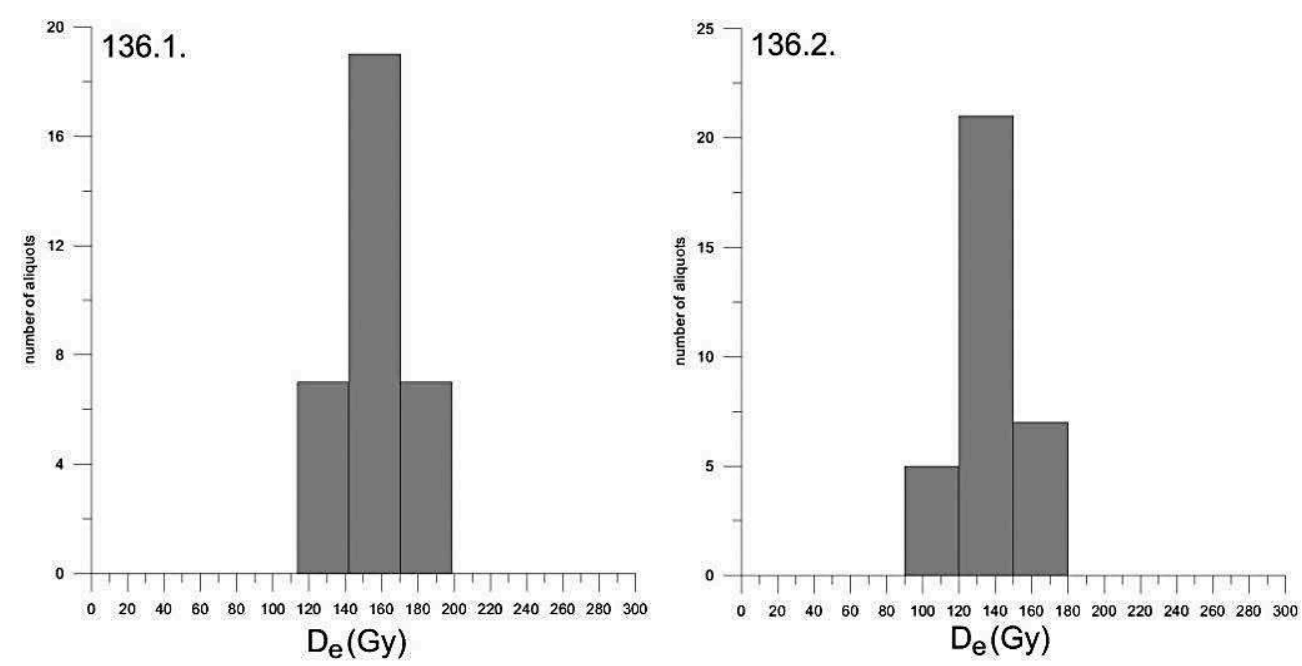

Table 2: Langeais. La Roche-Cotard II. OSL ages calculated with the average equivalent dose of the samples.

\begin{tabular}{|c|c|c|c|c|c|c|c|c|c|c|c|c|c|c|c|c|}
\hline \multirow{2}{*}{$\begin{array}{c}\text { sample } \\
136.1 .\end{array}$} & \multirow{2}{*}{\begin{tabular}{|c|}
$\begin{array}{c}\text { depth } \\
\text { (cm) }\end{array}$ \\
180 \\
\end{tabular}} & \multicolumn{2}{|c|}{$\begin{array}{c}\mathrm{U} \\
(\mathrm{ppm})\end{array}$} & \multicolumn{2}{|c|}{$\begin{array}{c}\text { Th } \\
\text { (ppm) }\end{array}$} & \multicolumn{2}{|c|}{$\begin{array}{l}\mathrm{K} \\
(\%)\end{array}$} & \multicolumn{3}{|c|}{$\begin{array}{c}\text { equivalent } \\
\text { dose (Gy) }\end{array}$} & \multirow[b]{2}{*}{33} & \multirow{2}{*}{\begin{tabular}{|c}
$\begin{array}{c}\text { w.c. } \\
\mathbf{\%}\end{array}$ \\
10,4 \\
\end{tabular}} & \multicolumn{2}{|c|}{$\begin{array}{c}\text { dose rate } \\
\text { (Gy/ka) }\end{array}$} & \multicolumn{2}{|c|}{$\begin{array}{c}\text { OSL age } \\
\text { (ka) }\end{array}$} \\
\hline & & 1,29 & $\pm 0,02$ & 5,45 & $\pm 0,10$ & 1,31 & $\pm 0,01$ & 156,15 & & & & & 2,06 & $\pm 0,15$ & 75,6 & $\pm 5,8$ \\
\hline 136.2. & 160 & 1,22 & $\pm 0,02$ & 5,49 & $\pm 0,09$ & 1,43 & $\pm 0,01$ & 138,18 & & & 33 & 13,3 & 2,10 & $\pm 0,15$ & 65,7 & $\pm 5,0$ \\
\hline
\end{tabular}

Current and saturated water content of the samples was measured; for sample age dating we used the average value ( 10 and $13 \%$ water content). Dose rates of the sediments were calculated based on laboratory high-resolution gamma spectrometry measurement (Canberra GC3020) of bulk samples using the conversion factors of Adamiec and Aitken (1998). In the case of medium water content the dose rates are 2.06 $\pm 0.15 \mathrm{~Gy} / \mathrm{ka}$ for sample 136.1 and 2, $10 \pm 0.15 \mathrm{~Gy} / \mathrm{ka}$ for sample 136.2 (tab., Thamó-Bozsó et al. 2015).

The age of the sample from layer $6 \mathrm{f}$ (RSC / LSO / 9), identified by the laboratory under the number MFGI / 136.2, was $65.7 \pm 5.0 \mathrm{ka}$ (tab. 2). The age of the sample from layer 7c, the one containing the Mousterian level and the "mask" (RSC / LSO / 8), identified by the laboratory as MFGI / 136.1, was 75.6 $\pm 5.8 \mathrm{ka}$ (fig. 8).

\section{Acknowledgements}

For helpful discussion Prof. Andrew Murray (Aarhus University, Denmark) is gratefully acknowledged. In the Geological and Geophysical Institute of Hungary Attila Nagy, Mariann Török-Sinka and Péter Cserny are thanked for gamma spectrometry measurements, Judit Füri and Miklósné Bátori for the help in luminescence measurements and sample preparation, and Zsolt Horváth for the measurement of water content. 


\section{References}

ADAMIEC G., AITKEN M.J. 1998 - Dose-rate conversion factors: update. Ancient TL 16, p. 37-50.

AITKEN M.J. 1998 - An Introduction to Optical Dating. The Dating of Quaternary Sediments by the Use of Photon-stimulated Luminescence. Oxford University Press, Oxford.

THAMÓ-BOZSÓ E., NAGY A., FÜRI J., TÖRÖK-SINKA M., BÁTORI M-NÉ, HORVÁTH ZS., CSERNY P. 2015 - Results of luminescence dating of samples from La Roche-Cotard (France). Manucript. Geological and Geophysical Institute of Hungary, Department of Geochemistry and Laboratories. Inedit report

WINTLE A., MURRAY A.S. 2006 - A review of quartz optically stimulated luminescence characteristics and their relevance in single-aliquot regeneration dating protocols. Radiation Measurements 41, p. 369-391.

\section{ABSTRACTS}

The «mask » of La Roche-Cotard was discovered in a layer containing a characteristic Middle Paleolithic lithic industry. After a first ${ }^{14} \mathrm{C}$ result of $32 \mathrm{ka} \mathrm{BP}$, two further ${ }^{14} \mathrm{C}$ dates now assign the layer to more than $40 \mathrm{ka}$, but above all an OSL date obtained on quartz attributes to the layer containing the "mask» an age of $75.6 \pm 5.8 \mathrm{ka}$. This new result confirms that $14 \mathrm{C}$ dates with Accelerator Mass Spectrometry, obtained on bones of that layer are beyond the limit of validity of the radiocarbon dating method. We present the principle of the method of luminescence dating that should be retained for the Neanderthal occupation of the Roche Cotard II level 7 and its implications.

INDEX

Keywords: Middle Palaeolithic, Neanderthal, Symbolic, Luminescence dating

\section{AUTHORS}

\section{JEAN-CLAUDE MARQUET}

Chercheur associé au Laboratoire Archéologie et Territoires Tours - jcmarquet@wanadoo.fr

\section{MICHEL LORBLANCHET}

Directeur de recherches honoraire au CNRS

\section{CHRISTINE OBERLIN}

Centre de Datation par le Radiocarbone UMR 5138 Archéométrie et Archéologie, 40 boulevard Niels Bohr, FR-69622 Villeurbanne cedex

\section{EDIT THAMO-BOZSO}

Geological and Geophysical Institute of Hungary, H-1143 Budapest, Stefánia 14. 


\section{THIERRY AUBRY}

Fundação Côa Parque, P-Vila Nova de Foz Côa 